J. Perinat. Med. 12 (1984) 201

\section{Effect of myo-inositol on the glycerophospholipid composition of adult and fetal rat lung tissue}

\author{
J. G. Quirk, Jr.*, B. Baumgarten, J. E. Bleasdale
}

Department of Obstetrics/Gynecology and Biochemistry, and Cecil H. and Ida Green Center for Reproductive Biology Sciences, University of Texas Health Science Center at Dallas, Dallas, Texas, USA

* J. G. Quirk is the recipient of a Special Emphasis Research Career Award (AM00883)

\section{Introduction}

In many species, including man, the second most abundant lipid in lung surfactant is phosphatidylglycerol (PG) which may comprise $10 \%$ or more of the total lipid in surfactant from mature lungs [20]. Interest in surfactant PG was stimulated by the finding that surfactant obtained from tracheal aspirates of full-term infants contained significant amounts of PG while this lipid was absent from the surfactant of premature infants [13]. Infants delivered before their surfactant contained a large amount of PG were at greater risk of succumbing to hyaline membrane disease. During lung development in the human and in other species, the PG content of surfactant rises with a concomitant fall in phosphatidylinositol (PI) content. It has been proposed that the relative rates of synthesis of PI and PG for surfactant may be influenced by the availability of myo-inositol in the lung $[3,15]$. In many tissues, the limited amount of CDP-diacylglycerol that is present likely restricts the biosynthesis of both PI and PG and it has been observed in vitro that the metabolic fate of CDPdiacylglycerol is influenced by the extracellular concentration of myo-inositol $[8,10,11]$. It has been observed also that excess myo-inositol administered to adult rabbits decreased surfactant PG and increased surfactant PI [14]. We have examined previously myo-inositol homeostasis in the fetal rabbit [3] and in the human fetus [21]. Based on the results of those studies we concluded that lung development in the human and in the rabbit is accompanied by decreased availability of myo-inositol for surfactant PI biosynthesis. In addition, we observed that myo-inositol (in concentrations similar to those measured in vivo) affected the incorporation of $\left\{{ }^{14} \mathrm{C}\right\}$ glycerol into glycerophospholipids by fetal rabbit lung explants [18] and by type II pneumonocytes isolated from adult rat lung [4]. As the myo-inositol content of the culture medium was increased, PI biosynthesis was stimulated at the expense of PG biosynthesis. In the present investigation myo-inositol was administered chronically to nonpregnant rats and to pregnant rats and the effect of this treatment on the glycerophospholipid composition of lung tissue and lung lavage was measured. In addition, the influence of myo-inositol administration to pregnant rats on the glycerophospholipid composition of lung tissue of their fetuses was investigated.

\section{Materials and methods}

Sprague-Dawley rats were purchased from HoLTZMAN (Madison, WI). The time of conception of the pregnant rats was known to within 12 hours. Throughout the experiment, the dams had free 
access to standard laboratory chow and drinking water. For 5 days before sacrifice, the dams received twice daily intraperitoneal injections of myo-inositol (180 mg) (SIGMA, St. Louis, MO) or saline. The group of rats injected with myoinositol also had drinking water containing myoinositol $(7 \% \mathrm{w} / \mathrm{v}$.). Blood samples were obtained from the tail vein of the rats and processed for measurement of myo-inositol [3].

In experiments utilizing pregnant rats, the animals were sacrificed on day 18 or day 21 of gestation with a lethal dose of Nembutal. Fetuses were removed quickly and fetal blood was obtained from decapitated fetuses using a capillary pipette. Fetal lungs were removed and kept at $4^{\circ} \mathrm{C}$ until processed. In all studies, alveolar material was obtained from adult animals by lavaging the lungs with three $10 \mathrm{ml}$ aliquots of $0.9 \% \mathrm{NaCl}$ via a tracheal cannula. The lungs were then dissected from the thorax and kept at $4^{\circ} \mathrm{C}$ until processed further.

myo-Inositol was measured in adult and fetal blood by gas-liquid chromatography of its trimethylsilyl (TMS) derivative as described previously [3]. The amount of TMS-myo-inositol in each extract was computed by measurement of peak area relative to the peak areas obtained with

Tab. I. Effect on myo-inositol administration on concentration of myo-inositol in adult and fetal rat serum

\begin{tabular}{|c|c|c|}
\hline & \multicolumn{2}{|l|}{ myo-Inositol $(\mu \mathrm{m})$} \\
\hline & Treatment & \\
\hline & Saline & myo-Inositol \\
\hline $\begin{array}{l}\text { Adult } \\
\text { Nonpregnant } \\
\text { Pregnant }\end{array}$ & $\begin{array}{l}34 \pm 2(54)^{*} \\
65 \pm 11(65)\end{array}$ & $\begin{array}{l}456 \pm 202(51) \\
670 \pm 155(72)\end{array}$ \\
\hline $\begin{array}{l}\text { Fetus } \\
\text { Day } 18 \\
\text { Day } 21\end{array}$ & $\begin{array}{ll}313 \pm 71 & (4)^{* *} \\
234 \pm 12 & (8)\end{array}$ & $\begin{aligned} 1177 & \pm 198 \\
517 & \pm 61\end{aligned}$ \\
\hline
\end{tabular}

The values (Mean $\pm S E$ ) for adult rats represent all measurements obtained on days 1,3 , and 5 of treatment. The values (Mean $\pm \mathrm{SE}$ ) for fetuses represent pooled blood from littermates. Numbers in parentheses are number of determinations.

* .01 compared to saline treated pregnant rats

** .05 compared to saline treated day 21 fetuses known amounts of authentic TMS-myo-inositol (SIGMA). The values for serum myo-inositol concentration were corrected for total recovery of tracer myo- $\left(2-{ }^{3} \mathrm{H}\right)$ inositol added to each initial extract. Total recovery of the myo- $\left(2-{ }^{3} \mathrm{H}\right)$ inositol throughout the procedure ranged between 67 and $75 \%$.

For determination of glycerophospholipid composition, lung lavage material was centrifuged ( $600 \mathrm{~g} \times 10 \mathrm{~min})$ at $4{ }^{\circ} \mathrm{C}$ and lipids were extracted from the supernatant fluid and from lung tissue homogenates as described elsewhere [2]. Phospholipids were separated by 2-dimensional thin-layer chromatography [23] and areas of thin-layer chromatograms containing individual phospholipid classes were transferred to test tubes. Lipid phosphorus was measured as described by AMES and DUBIN [9].

\section{Results}

The concentration of myo-inositol in the serum of pregnant rats was significantly higher than that in nonpregnant rats $(p<.01)$. Treatment of the rats (pregnant and nonpregnant) with myo-inositol resulted in elevated serum concentrations of myoinositol throughout the 5 days of the experiment (Tab. I). Consistently, however, there was a tendency for the serum myo-inositol concentration in myo-inositol treated animals" to decrease over the course of the experiment (Fig. 1). Between day 18 and day 21 of development, there was a significant decrease in serum myo-inositol concentrations in the fetuses of saline treated rats $(p<.05)$. Treatment of the pregnant dams with myo-inositol resulted in a significant elevation in fetal serum concentrations of myo-inositol on both day 18 and day 21 of gestation. Interestingly, however, the concentration of myo-inositol in the serum of fetuses of rats that received myo-inositol was still greater on day 18 than on day 21 , and so was analogous to the normal decline observed in fetuses of the saline treated rats (Tab. I).

After 5 days of myo-inositol administration, the glycerophospholipid composition of lung tissue and lavage was analyzed. In both pregnant and nonpregnant adult rats, there were significant decreases in the PG content of lung tissue $(p<.02)$ 


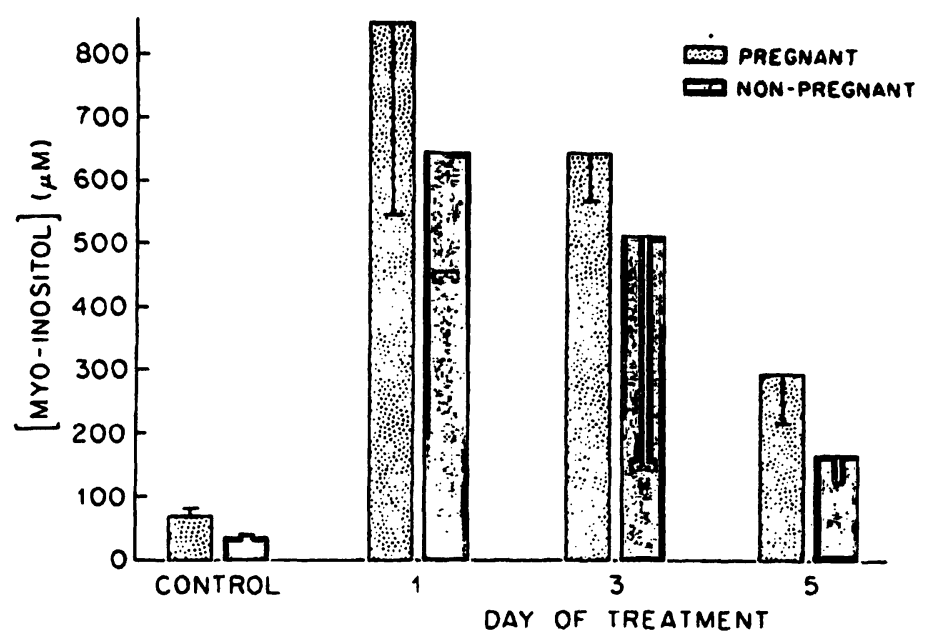

Fig. 1. The effect of myo-inositol administration on the serum concentration of myo-inositol in pregnant and nonpregnant rats. Each bar represents the mean value \pm S.E. from between 17 and 25 measurements.

and lung lavage material $(\mathrm{p}<.01)$. These decreases were associated with a significant increase in the PI content of lung tissue $(\mathrm{p}<.01)$ and of lung lavage material $(\mathrm{p}<.001)$. The phosphatidylcholine, phosphatidylserine and phosphatidylethanolamine content of adult lung tissues and lung lavage material were not affected by myo-inositol administration (Tab. II). Although the administration of myo-inositol to adult rats resulted in a decrease in the PG content of their surfactant it did not appear to affect drastically the health of these animals. Nonpregnant adult rats treated with myoinositol had the same respiratory rate as the saline treated rats and they maintained normal body weight. Similarly, pregnant rats treated with myoinositol had normal respiratory rates, weight gains and litter sizes (data not shown).

Having increased myo-inositol availability to the fetuses of pregnant rats treated with myo-inositol, the effect of this increased availability on the glycerophospholipid composition of developing fetal lung tissue was investigated. Between day 18 and day 21 of gestation, there was a significant increase $(p<.05)$ in the PG content (expressed as percent of total glycerophospholipid) of lung tissue obtained from fetuses of the saline treated dams with a concomitant decrease in PI content $(p<.05)$. Administration of myo-inositol to pregnant rats for five days resulted in a significant decrease in the PG content of fetal lung tissues at both day $18(p<.05)$ and day $21(p<.01)$ of gestation and a significant increase $(p<.05)$ in the PI content of lung tissues of day 21 fetuses (Tab. III). myo-Inositol treatment had no effect on the phosphatidylcholine, phosphatidylserine or phosphatidylethanolamine content of fetal lung tissues at day 18 or day 21 of gestation.

The effect of myo-inositol administration on glycerophospholipid compositions was most striking when the phosphatidylglycerol to phosphatidylinositol ratio (PG/PI ratio) of the different groups was compared (Fig. 2). As expected, the PG/PI ratio of lung lavage material was much higher than

Tab. II. Glycerophospholipid composition of adult rat lung tissue and lung lavage

\begin{tabular}{|c|c|c|c|c|}
\hline \multirow{2}{*}{ Glycerophospholipid } & \multicolumn{2}{|l|}{ Lung Tissue } & \multicolumn{2}{|l|}{ Lung Lavage } \\
\hline & \multicolumn{4}{|c|}{ Treatment } \\
\hline $\mathrm{n}$ & 23 & 25 & 19 & 23 \\
\hline
\end{tabular}

The data are expressed as mole percent of total glycerophospholipid (Mean $<\mathrm{SE}$ ). (* $\mathrm{P}<.02, * * \mathrm{p}<.01, * * * \mathrm{p}<.001$, when compared to rats treated with myo-inositol). Values for "other" phospholipids were calculated as the difference between the total amount of lipid phosphorus applied to the thin-layer chromatography plate and the amount recovered in the five glycerophospholipids listed above. 
Tab. III. Glycerophospholipid composition of fetal rat lung tissue

if

Day 18 Fetus

Day 21 Fetus

Treatment

\begin{tabular}{lcccc}
\cline { 2 - 4 } Glycerophospholipid & Saline & myo-Inositol & Saline & myo-Inositol \\
\hline 11 & \multicolumn{1}{l}{8} & \multicolumn{1}{l}{12} & \multicolumn{1}{c}{12} \\
\hline Phosphatidylglycerol & $3.7 \pm 0.4^{*}$ & $2.4 \pm 0.3$ & $5.5 \pm 0.9 *$ & $2.5 \pm 0.5$ \\
Phosphatidylinositol & $5.5 \pm 0.4$ & $5.7 \pm 0.3$ & $2.7 \pm 0.7^{*}$ & $5.5 \pm 0.5$ \\
Phosphatidylcholine & $53.4 \pm 3.5$ & $54.2 \pm 0.7$ & $56.7 \pm 2.4$ & $55.4 \pm 1.7$ \\
Phosphatidylserine & $8.8 \pm 0.8$ & $9.1 \pm 0.3$ & $6.2 \pm 0.2$ & $7.3 \pm 0.6$ \\
Phosphatidylethanolamine & $7.8 \pm 0.6$ & $7.6 \pm 1.0$ & $5.8 \pm 0.4$ & $6.3 \pm 0.6$ \\
Other & 21.2 & 21.2 & 22.8 & 23.4 \\
\hline
\end{tabular}

The data are expressed as mole percent of total glycerophospholipid (Mean $\pm \mathrm{SE})$. (* $\mathrm{p}<.05$ when compared to fetuses of mothers treated with myo-inositol). Values for "other" phospholipids were calculated as the difference between the total amount of lipid phosphorus applied to the thin-layer chromatography plate and the amount recovered in the five glycerophospholipids listed above.

that of lung tissue. Treatment with myo-inositol resulted in a highly significant $(\mathrm{p}<.001)$ decrease in the PG/PI ratio in both lung tissue and in lung lavage material of adult rats. The PG/PI ratio of fetal lung tissue increased normally between day 18 and day 21 of gestation $(p<.05)$ but the administration of myo-inositol to pregnant rats prevented this normal developmental increase in the PG/PI ratio of lung tissues of their fetuses $(p<.05)$. Although the phosphatidylcholine,
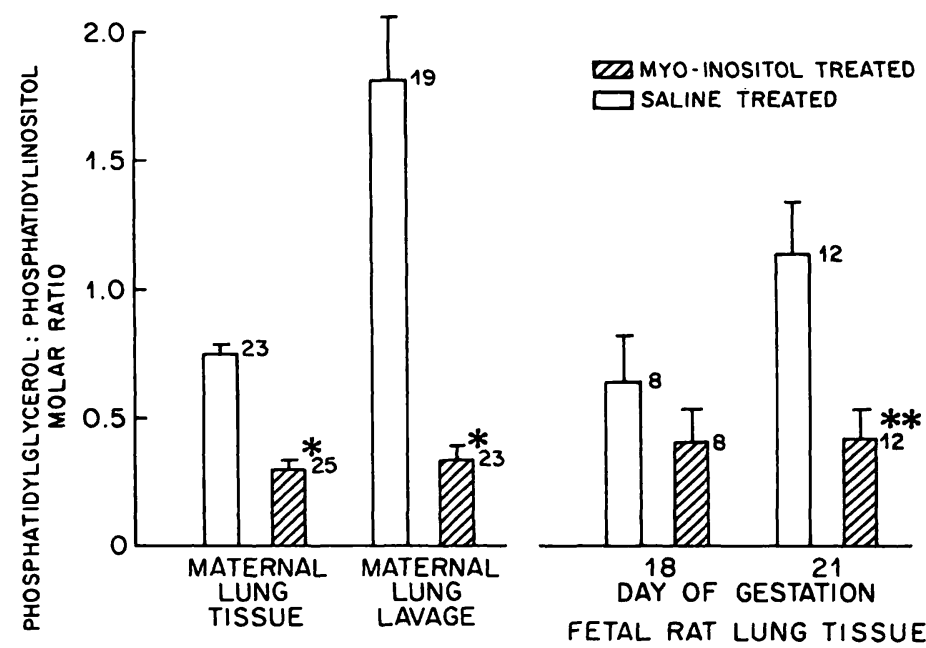

Fig. 2. Phosphatidylglycerol: Phosphatidylinositol molar ratios in adult and fetal lung tissues and adult lung lavage in rats treated with myo-inositol or saline. Each bar represents the mean value $\pm S$.E. from the number of measurements depicted adjacent to each bar $(* p<.001$; $* * \mathrm{p}<.05)$. phosphatidylserine and phosphatidylethanolamine content of adult and fetal lung tissues and lung lavage material was unaffected by myo-inositol treatment, the PG/PI ratios of adult lung tissues, adult lung lavage, day 18 fetal lung tissues, and day 21 fetal lung tissues were all reduced to very similar low values.

\section{Discussion}

As part of an investigation "of the influence of myo-inositol on lung surfactant composition, pregnant and nonpregnant rats were treated with myoinositol. The concentration of myo-inositol in the serum of pregnant rats was significantly greater than that in the serum of nonpregnant rats. Possible explanations for this finding include increased myo-inositol biosynthesis in maternal tissues and decreased renal clearance of myoinositol by the maternal kidney. Increased synthesis is a likely possibility because myo-inositol synthesis in several adult rat tissues is known to be under hormonal control [17]. The putative rate limiting enzyme in myo-inositol biosynthesis is D-glucose 6-phosphate:1L-myo-inositol 1-phosphate cyclase (cyclase) [9]. In the rat, cyclase activity in primary and secondary sex organs is regulated by pituitary hormones whereas cyclase activity in the liver is regulated by thyroid hor- 
mones [17]. It is possible that gonadotropic hormones synthesized during pregnancy might exert an effect similar to that of pituitary hormones.

In both pregnant and nonpregnant rats, treatment with myo-inositol resulted in a marked increase in serum myo-inositol concentrations. Over the course of the 5 day treatment period, however, the high concentration of myo-inositol in the serum of treated rats consistently declined toward normal. This may reflect altered renal metabolism or clearance of myo-inositol since in man at least, the kidney is the major regulator of serum myoinositol [7]. The human kidney both synthesizes and oxidizes large amounts of myo-inositol and the rate of oxidation of myo-inositol appears to depend upon the plasma concentration of myoinositol and renal plasma flow [7].

The finding that the concentration of myo-inositol in fetal rat serum decreases between day 18 and day 21 is consistent with previous observations in the rabbit [3] and in man [21] and is compatible with the proposition that late in gestation there is a decreasing availability of myo-inositol for PI biosynthesis in fetal rat lung. myo-Inositol availability to the fetal lung may therefore be an important regulator of the developmental change from the production of a surfactant rich in PI to one rich in PG. The present observation that the concentration of myo-inositol in fetal rat serum declines at a time when the PG content of lung tissue increases is consistent with such a view. Similar changes in the extracellular concentration of myo-inositol were found to affect the relative rates of synthesis of PI and PG by rat type II pneumonocytes in vitro [4].

Treatment of pregnant rats with myo-inositol effected a significant elevation in myo-inositol concentration in the serum of their fetuses at both day 18 and day 21 of gestation. This most likely reflects transplacental uptake of myo-inositol although in previous studies employing sheep, no transplacental transport of myo-inositol to the fetus could be detected when a large amount of myo-inositol was administered in a single intravenous injection to the pregnant ewe $[5,19]$. In addition to species differences, there are other possible reasons for this discrepancy. Previous studies involved short-term infusion of myoinositol. If the bulk of the administered myoinositol is rapidly cleared from the maternal circulation by the kidneys, there may be only limited exposure of the fetus to high concentrations of myo-inositol. If the rate of uptake of myo-inositol by the placenta is slow, a rather long exposure to large amounts of myo-inositol may be required before a significant change in the concentration of myo-inositol in fetal serum is observed.

It has been reported previously that the phosphatidylethanolamine content of adult rat lung tissue is greater than that reported here [22]. An explanation for this difference may be that ethanolamine plasmalogen which co-chromatographs with phosphatidylethanolamine in most thin-layer chromatographic systems may have been included with the total phosphatidyle thanolamine measured in previous investigations. In the present investigation, however, the acidic extraction conditions that were employed resulted in the hydrolysis of ethanolamine plasmalogen and so it would not have contributed to the measured amounts of phosphatidylethanolamine [16].

The presence of myo-inositol in increased concentrations in maternal and fetal rat serum resulted in a significantly reduced $\mathrm{PG} / \mathrm{PI}$ ratio in lung tissue and lung lavage material without affecting the amount of phosphatidylcholine, phosphatidylserine or phosphatidylethanolamine present. This finding extends the previous observation that myoinositol administration to nonpregnant adult rabbits resulted in a decreased PG/PI ratio in lung lavage material from adult lungs [14]. A reciprocal relationship between the synthesis of $P G$ and that of PI has been observed in several tissues $[8,11]$ and likely reflects competition for the limited amount of CDP-diacylglycerol that is the common precursor of both these glycerophospholipids. Competition for CDP-diacylglycerol appears to be influenced by the availability of myo-inositol such that an increase in the extracellular concentration of myo-inositol results in the stimulation of PI biosynthesis at the expense of PG biosynthesis.

In the present investigation, increasing myoinositol availability to the fetus prevented the production of a surfactant characteristic of mature 
lungs, i.e., one rich in PG. This finding is compatible with the observation that PI synthesis is favored over that of PG in rat type II pneumonocytes in vitro when the extracellular concentration of myo-inositol exceeds $300 \mu \mathrm{m}$ [4]. Although that investigation was performed employing type II pneumonocytes isolated from adult rats, it was shown in another investigation that, at least in the rabbit, the characteristics of myo-inositol uptake by slices of adult and fetal lung are very similar [3]. The present findings also complement the observation that when insulin was infused into pregnant rabbits the concentrations of glucose, insulin, and myo-inositol in fetal serum were decreased in association with the production by the fetus of a lung surfactant enriched in PG [15].

We speculate that myo-inositol may be involved also in the delayed appearance of PG in the lung surfactant of the human fetus in pregnancies complicated by diabetes mellitus. Patients with dia-

\section{Summary}

In many species including man, the second most abundant lipid in lung surfactant is phosphatidylglycerol (PG) which may comprise $10 \%$ of the total lipid in surfactant from mature lungs. Infants delivered before their surfactant contained a large amount of PG are at greater risk of succumbing to hyaline membrane disease. Regulation of the PG content of lung surfactant is not understood completely, but the reciprocal changes in the amount of phosphatidylinositol (PI) and PG in surfactant as the lung mature are suggestive of regulation at the level of a common precursor.

The immediate common precursor of PI and PG is CDPdiacylglycerol which is found in only small amounts in most mammalian cells and likely restricts the biosynthesis of both PI and PG. It has been observed in several species that the enzymes that synthesize PI and PG compete for the limited amount of CPD-diacylglycerol and this competition is influenced by the availability of myo-inositol. We and others have presented evidence that myo-inositol availability in the developing lung may be an important factor in the regulation of lung surfactant composition.

In the present investigation, myo-inositol was administered chronically to nonpregnant and to pregnant rats and the effect of this treatment on the glycerophospholipid composition of lung tissue and lung lavage was measured. In addition, the influence of myo-inositol administration to pregnant rats on the glycerophospholipid composition of lung tissue of their fetuses was investigated. The concentration of myo-inositol in adult and fetal blood was measured by gas-liquid chromatography of its trimethylsilyl derivative. For determination of glycerophospholipid betes mellitus are know to have myo-inositol intolerance [6] and this has been implicated in the etiology of diabetic neuropathy [12]. This intolerance is corrected by insulin therapy [6]. The imbalance in myo-inositol homeostasis in the pregnant diabetic woman might affect adversely myoinositol homeostasis in her fetus. Specifically, increased placental transfer of myo-inositol (resulting from high concentrations of myoinositol in maternal blood) and/or increased synthesis de novo by the fetus (supported by increased glucose availability to the fetus) might result in a delay in the appearance of a lung surfactant enriched with PG. The results of this investigation support the hypothesis that factors which affect myo-inositol homeostasis result in an altered glycerophospholipid composition of surfactant in adults and fetuses and justify an examination of myo-inositol homeostasis in human pregnancies complicated by diabetes mellitus.

composition, the total lipid extracts of lung tissues and lung lavage were separated by 2-dimensional thin-layer chromatography and quantified by lipid phosphorus assay of individual spots.

The concentration of myo-inositol in the serum of pregnant rats was significantly higher than in nonpregnant rats (Tab. I, Fig. 1). Treatment of the rats with myo-inositol resulted in a significant elevation of serum concentrations of myo-inositol throughout the experimental period. Between day 18 and day 21 of the gestation there was a significant decrease in serum myo-inositol concentrations in fetuses of saline treated rats. Treatment of the pregnant dams with myo-inositol resulted in a significant elevation in fetal serum concentrations of myo-inositol on both day 18 and day 21 of gestation (Tab. I).

After 5 days of myo-inositol administration, the glycerophospholipid composition of lung tissue and lung lavage was analyzed. In both pregnant and nonpregnant rats, there was a significant decrease in the PG content of lung tissue $(p<.02)$ and lung lavage material $(p<.01)$ associated with a significant increase in their PI content ( $p<.01$ and $p<.001$, respectively). The content of other measured glycerophospholipids was unaffected by treatment (Tab. II).

Between day 18 and day 21 of gestation, there was significant increase $(p<.05)$ in the PG content with a concomitant decrease in PI content $(p<.05)$ of lung tissue obtained from fetuses of saline treated dams. Administration of myo-inositol to pregnant rats resulted in a significant decrease in the PG content of fetal lung tissue on day $18(\mathrm{p}<.05)$ and day $21(\mathrm{p}<.01)$ and a significant 
increase $(p<.05)$ in the PI content of lung tissue of day 21 fetuses (Tab. III).

The PG/PI ratio of the various groups were compared. The ratio, as expected, was much higher for lung lavage material than lung tissue in the adult rats. Similarly, the PG/PI ratio in fetal lung tissue was higher on day 21 than on day 18 of gestation. Following myo-inositol treatment, the PG/PI ratio of adult lung tissue, adult lung lavage, day 18 fetal lung tissue and day 21 fetal lung tissue were all reduced to very similar ratios (Fig. 2).

These findings extend previous observations that myoinositol affects the PG and PI content of lung lavage material. Competition for CDP-diacylglycerol appears to be influenced by the availability of myo-inositol such that an increased extracellular concentration of myoinositol results in the simulation of PI biosynthesis at the expense of PG biosynthesis. We speculate that myoinositol may be involved in the delayed appearance of PG in the lung surfactant of the human fetus in pregnancies complicated by diabetes mellitus. Patients with diabetes are known to have myo-inositol intolerance that is corrected by insulin therapy. Increased placental transfer of myo-inositol (from high maternal blood concentrations) and/or increased synthesis de novo by the fetus (supported by increased glucose availability) might result in a delay in the appearance of a lung surfactant enriched in PG.

Keywords: Fetal lung tissue, glycerophospholipids, myo-inositol, phosphatidylglycerol, phosphatidylinositol, rat lungs lavage.

\section{Zusammenfassung}

Einfluß von Myo-Inositol auf die Zusammensetzung der Glycerophospholipide im Lungengewebe adulter bzw. fetaler Ratten

Bei vielen Spezies, so auch beim Menschen, stellt das Phosphatidylglycerol (PG) mit einem Anteil von $10 \%$ an den Gesamtlipiden in der Surfactant reifer Lungen die zweithäufigste Verbindung dar. Enthält die Surfactant nicht ausreichende Mengen an PG, so ist das Risiko für ein hyalines Membransyndrom erhöht. Wie der PG-Gehalt in der oberflächenaktiven Substanz der Lunge reguliert wird, ist nicht klar; da sich jedoch während der Lungenreifung Phosphatidylinositol (PI) und PG reziprok verändern, ist eine Regulation über eine gemeinsame Vorläufersubstanz anzunehmen.

Die unmittelbare Vorstufe von PI und PG ist das CDPDiacylglycerol, das in den meisten Säugerzellen nur in geringen Mengen vorhanden ist und die Biosynthese von PI und PG limitiert. Bei vielen Spezies wurde beobachtet, daß die Synthese des CDP-Diacylglycerols über einen kompetitiven enzymatischen Prozeß gesteuert wird und dieser Prozeß von der verfügbaren Menge an Myo-Inositol abhängt. Wir und andere Arbeitsgruppen haben gezeigt, daß während der Lungenreifung das Myo-Inositol ein wichtiger Faktor bei der Regulation der Surfactantzusammensetzung ist.

In der vorliegenden Untersuchung wurde Myo-Inositol kontinuierlich an nicht trächtige und trächtige Ratten verabreicht. Wir haben den Einfluß dieser Behandlung auf die Glycerophospholipidzusammensetzung im Lungengewebe und in der Lungenlavage bestimmt. Darüber hinaus untersuchten wir den Einfluß einer Myo-Inositolgabe an trächtige Ratten auf die Glycerophospholipidzusammensetzung im Lungengewebe der Feten. Die MyoInositolkonzentration im adulten wie im fetalen. Blut wurde über eine Gas-Flüssigkeitschromatographie anhand der Trimethylsilylderivate gemessen. Zur Bestimmung der Glycerophospholipidzusammensetzung wurden die Lipidextrakte aus dem Lungengewebe und der Lungenlavage dünnschichtchromatographisch aufgetrennt und die \$pots über einen Lipidphosphatansatz quantifiziert.

Die Myo-Inositolkonzentration lag im Serum trächtiger Ratten signifikant über der normaler Ratten (Tab. I,
Fig. 1). Die Myo-Inositolbehandlung führte zu einem signifikanten Anstieg der Serumkonzentration über den gesamten Untersuchungszeitraum. Zwischen dem 18. und 21. Tag der Tragezeit kam es bei den Feten der mit einer Salzlösung behandelten Ratten zu einem signifikanten Abfall der Myo-Inositolkonzentrationen im Serum. Die Behandlung der Muttertiere mit Myo-Inositol führte dagegen zu einem signifikanten Anstieg der MyoInositolkonzentration im fetalen Serum sowohl am 18. wie auch am 21. Tag der Tragezeit (Tab. I).

Nach fünftägiger Myo-Inositolgabe wurde die Glycerophospholipidzusammensetzung im Lungengewebe und in der Lungenlavage analysiert. Sowohl bei trächtigen wie auch bei normalen Ratten kam es zu einem signifikanten Abfall des PG-Gehaltes im Lungengewebe $(p<0,02)$ und im Material der Lungenlavage $(p<0,01)$; auf der anderen Seite stieg der PI-Anteil signifikant an ( $p<0,01$ bzw. $p<0,001$ ). Die Konzentrationen anderer Glycerophospholipide änderten sich unter der. Therapie nicht (Tab. II).

Waren die Muttertiere mit einer Salzlösung behandelt, stieg zwischen dem 18. und 21. Tag der Tragezeit der PG-Gehalt im fetalen Lungengewebe signifikant an $(p<0,05)$. Parallel dazu kam es zu einem Abfall des PI $(p<0,05)$. Die Gabe von Myo-Inositol an trächtige Ratten führte dagegen zu einem signifikanten Abfall des PG im fetalen Lungengewebe am 18. bzw. 21. Tag ( $p<0,05$ bzw. $p<0,01$ ) und zu einem Anstieg des PI im Lungengewebe bei Feten am 21. Tag (Tab. III).

Wir haben die PG/PI-Ratio in den verschiedenen Gruppen miteinander verglichen. Wie zu erwarten, war bei adulten Tieren der Quotient im Lavagematerial viel größer als im Lungengewebe. Ebenso lag die PG/PI-Ratio im fetalen Lungengewebe am 21. Tag über der am 18. Tag. Nach Myo-Inositolbehandlung waren die PG/PI-Quotienten von adultem Lungengewebe und Lavage sowie von fetalem Lungengewebe vom 18. und 21. Tag sämtlich auf vergleichbare Werte reduziert (Fig. 2).

Diese Ergebnisse bestätigen die früheren Beobachtungen, daß Myo-Inositol eine Wirkung auf den PG- und PI-Gehalt im Lavagematerial hat. Es scheint, daß die Konkurrenz um das CDP-Diacylglycerol durch Myo-Inositol beeinflußt 
wird: eine erhöhte extrazelluläre Konzentration an MyoInositol stimuliert die PI-Biosynthese auf Kosten der PG-Synthese. Bei diabetischen Schwangerschaften tritt das PG in der Oberflächensubstanz fetaler Lungen verzögert auf. Vielleicht kommt dabei dem Myo-Inositol eine Bedeutung zu. Diabetische Patienten haben nämlich ein Myo-Inositolüberangebot, das durch die Insulintherapie korrigiert wird. Ein vermehrter plazentarer Transport von Myo-Inositol (wegen hoher maternaler Konzentrationen) und/oder eine erhöhte fetale de-novo-Synthese (wegen eines vermehrten Glucose-Angebots) könnten dazu führen, daß PG in der Surfactant nur verzögert angereichert wird.

Schlüsselwörter: Fetales Lungengewebe, Glycerophospholipide, Myo-Inositol, Phosphatidylglycerol, Phosphatidylinositol, Rattenlungen-Lavage.

\section{Résumé}

Effet du myo-inositol sur la composition des glycerophospholipides des extraits pulmonaires adultes et fœtaux chez le rat

Dans de nombreuses espèces, y compris l'espèce humaine, le second lipide en abondance du surfactant pulmonaire est le phosphatidylgly cerol (PG) qui peut représenter $10 \%$ des lipides totaux du surfactant au niveau des poumons matures. Les enfants nés avant que leur surfactant contienne une grande quantité de $\mathrm{PG}$ sont à plus haut risque d'être atteints d'une maladie des membranes hyalines. La régulation de la teneur en PG du surfactant pulmonaire n'est pas entièrement comprise, mais les modifications réciproques des quantités de phosphatidylinositol (PI) et de PG suggèrent qu'il existe une régulation au niveau d'un précurseur commun.

Le précurseur commun immédiat du PI et du PG est le CDP-diacylglycérol qui n'est trouvé qu'en faible abondance dans les cellules de beaucoup mannifères, et ce précurseur limite vraissemblablement la biosynthèse à la fois du PI et du PG. On a observé dans de nombreuses espèces que les enzymes qui synthétisent le PI et le PG utilisent de façon compétitive les quantités limitées de CDP-diacylgly cérol et cette compétition est influencée par la disponibilité de myo-inositol. Nous avons prouvé ainsi que d'autres auteurs que la disponibilité de myo-inositol dans le poumon en croissance peut être un facteur important dans la régulation de la composition du surfactant pulmonaire.

Dans ce travail, nous avons administré du myo-inositol de façon chronique à des rattes gravides et non gravides et nous avons mesuré l'effet de ce traitement sur la composition des glycérophospholipides des tissus pulmonaires et des liquides de lavage pulmonaire. En outre, nous avons exploré l'influence de l'administration de myo-inositol à des rattes gravides sur la composition en glycerophospholipided des extraits pulmonaires de leurs fœtus. Nous avons mesuré la concentration de myo-inositol dans le sang des adultes et des fœtus par chromatographie en phase gazeuse et liquide de son dérivé trimethylsilyl. Pour la détermination de la composition des glycerophospholipides nous avons séparé les lipides totaux extraits des poumons et des produits de lavage pulmonaire par chromatographie à 2 dimensions en couche mince et nous les avons quantifiés par dosage phospholipidique dans chaque tâche.

La concentration de myo-inositol dans le sérum des rattes gravides est significativement plus élevée que celle des rattes non gravides (Tab. I, Fig. 1). Le traitement des rattes avec du myo-inositol entraîne une élévation significative des concentrations sériques de myo-inositol tout au long de l'expérimentation. Entre le 18ème jour et le 21ème jour de la gestation, il $\mathrm{y}$ a une diminution significative des concentrations de myo-inositol sérique chez les fœtus de rattes traitées par du sérum salé. Le traitement des mères gravides par myo-inositol entraîne une élévation significative des concentrations fœtales sériques de myoinositol à la fois au 18 ème et au 21 ème jour de gestation (Tab. I).

Au bout de 5 jours d'administration de myo-inositol, nous avons analysé la composition des glycérophospholipides des poumons et des liquides de lavage pulmonaire. Et chez le rattes gravides et chez les rattes non gravides, il y a une diminution significative de la teneur en PG des poumons $(p<0,02)$ et des produits de lavage pulmonaire $(p<0,01)$. Cette diminution est associée à une augmentation significative de leur teneur en PI $(p<0,01$ et $\mathrm{p}<0,001$, respectivement). La teneur des autres glycerophospholipides mesurés n'a pas été modifiée par le traitement (Tab. II).

Entre le 18 ème et le 21 ème jour de gestation, il y a une augmentation significative $(p<0,05)$ de la teneur en PG avec une diminution concomittante de la teneur en PI $(p<0,05)$ dans les poumons des fœtus dont les mères avaient été traitées par du sérum salé. L'administration de myo-inositol aux rattes gravides entraîne une diminution significative de la teneur en PG des poumons fœtaux à J $18(\mathrm{p}<0,05)$ et à $J 21(\mathrm{p}<0,01)$ ainsi qu'une augmentation significative $(p<0,05)$ de la teneur en PI des poumons des fœtus à $\mathrm{J} 21$ (Tab. III).

On a comparé les rapports PG/PI des différents groupes. Comme on s'y attendait, le rapport est plus élevé chez le rat adulte dans les produits de lavage pulmonaire que dans les poumons. De façon similaire, le rapport $\mathrm{PG} / \mathrm{PI}$ dans les poumons adultes, dans les produits de lavage chez l'adulte, et dans les poumons fœtaux à J 1.8 et à $\mathrm{J} 21$ sont tous diminués dans les proportions similaires (Fig. 2).

Ces données prolongent les observations antérieures qui démontraient que le myo-inositol agit sur la teneur en PG et PI du produit de lavage pulmonaire. La compétition pour le CDP-diacylglycerol apparaît comme influencée par la disponibilité du myo-inositol de telle sorte qu'une élévation de la concentration extra-cellulaire de myoinositol entraîne la stimulation de la bio-synthèse de PI au détriment de la bio-synthèse de P.G. Nous spéculons que l'on peut impliquer le myo-inositol dans l'apparition retardée du PG dans le surfactant pulmonaire du fœtus 
humain au cours des grossesses compliquées de diabète sucré. Les diabétiques sont connus pour avoir une intolérance au myo-inositol qui est corrigée par l'insulinothérapie. L'augmentation du transfert placentaire de myo-inositol (à partir des concentrations sanguines maternelles élevées) et/ou une augmentation de la synthèse de novo par le fœtus (grâce à une disponibilité accrue du glucose) peut entrainer un retard dans l'apparition du surfactant pulmonaire enrichi en PG.

Mots-clés: Glycérophospholipides, lavage pulmonaire chez le rat, myo-inositol, phosphatidylglycérol, phosphatidylinositol, tissu pulmonaire fotal.

Acknowledgement: Presented in part at the Fourth Annual Meeting of the Society of Perinatal Obstetricians, San Antonio, Texas, February 2-4, 1984.

Supported in part by grants from the National Institutes of Health (P01-HD13912 and R01HD14373).

Bibliography

[1] AMES, B. N., D. T. DUBIN: The role of polyamines in the neutralization of bacteriophage deoxyribonucleic acid. J. Biol. Chem. 235 (1960) 769

[2] BLEASDALE, J.E., P. WALLIS, P.C. MACDONALD et al.: Characterization of the forward and reverse reactions catalyzed by CDP-diacylglycerol: inositol transferase in rabbit lung tissue. Biochim. Biophys. Acta 575 (1979) 135

[3] BLEASDALE, J.E., M. C. MABERRY, J.G. QUIRK: myo-Inositol homeostasis in foetal rabbit lung. Biochem. J. 206 (1982) 43

[4] BLEASDALE, J. E., N. E. TYLER, F. N. BUSCH et al.: The influence of myo-inositol on phosphatidylglycerol synthesis by rat type II pneumonocytes. Biochem. J. 212 (1983) 811

[5] CAMPLING, J. D., D. A. NIXON: The inositol content of foetal fluids. J. Physiol. 126 (1954) 71

[6] CLEMENTS, R.S., Jr., R.REYNERTSON: Myoinositol metabolism in diabetes mellitus. Effect of insulin treatment. Diabetes 26 (1977) 215

[7] ClEmENTS, R. S., Jr., A. G. DIETHELM: The metabolism of myo-inositol by the human kidney. J. Lab. Clin. Med. 93 (1979) 210

[8] EICHBERG, J., J.GATES, G. HAUSER: The mechanism of modification by propranolol of the metabolism of phosphatidyl-CMP(CDP-diacylglycerol) and other lipids in the rat pineal gland. Biochim. Biophys. Acta 573 (1979) 90

[9] EISENBERG, F., Jr.: D-Myoinositol 1-phosphate as product of cyclization of glucose 6-phosphate and substrate for a specific phosphatase in rat testes. J. Biol. Chem. 242 (1967) 1375

[10] ESKO, J. D., C. R. H. RAET Z: Mutants of Chinese hamster ovary cells with altered membrane phospholipid composition. Replacement of phosphatidylinositol by phosphatidylglycerol in a myo-inositol auxotroph. J. Biol. Chem. 255 (1980) 255

[11] FREINKEL, N., C. EL YOUNSI, R.M.C. DAWSON: Inter-relations between the phospholipids of rat pancreatic islets during glucose stimulation and their response to medium inositol and tetracaine. Eur. J. Biochem. 59 (1975) 245
[12] GREenE, D. A., P. V. DE JESUS, Jr., A. I. WINEGRAD: Effects of insulin and dietary myoinositol on impaired peripheral motor nerve conduction velocity in acute streptozotocin diabetes. J. Clin. Invest. 55 (1975) 1326

[13] HALlMAN, M., M. KULOVICH, E. KIRKPATRICK et al.: Phosphatidylinositol and phosphatidylglycerol in amniotic fluid: Indices of lung maturity. Am. J. Obstet. Gynecol. 125 (1976) 613

[14] HALLMAN, M., B.L.EPSTEIN: Role of myo-inositol in the synthesis of phosphatidylglycerol and phosphatidylinositol in the lung. Biochem. Biophys. Res. Comm. 92 (1980) 1151

[15] HALLMAN, M., D. WERMER, B. L. EPSTEIN et al.: Effects of maternal insulin or glucose infusion on the fetus: Study on lung surfactant phospholipids, plasma myoinositol, and fetal growth in the rabbit. Am. J. Obstet. Gynecol. 142 (1982) 877

[16] HANAHAN, D. J.: Ether-linked lipids: Chemistry and methods of measurement. In: F. SNYDER: Ether Lipids: Chemistry and Biology. Academic Press, New York 1972

[17] HASEgAWA, R., F. EISENBERG, Jr.: Selective hormonal control of myo-inositol biosynthesis in reproductive organs and liver of the male rat. Proc. Natl. Acad. Sci. USA 78 (1981) 4863

[18] LONGMUIR, K. J., J.E. BLEASDALE, J. G. QUIRK et al.: Regulation of lamellar body acidic glycerophospholipid biosynthesis in fetal rabbit lung in organ culture. Biochim. Biophys. Acta 712 (1982) 356

[19] NIXON, D. A.: The concentration of free mesoinositol in the plasma of perfused sheep foetuses. Biol. Neonat. 12 (1968) 113

[20] Pfleger, R. C., H. G. ThOMAS: Beagle dog pulmonary surfactant lipids. Lipid composition of pulmonary tissue, exfoliated lining cells, and surfactant. Arch. Int. Med. 127 (1971) 863

[21] QUIRK, J. G., J. E. BLEASDALE: Myo-inositol homeostasis in the human fetus. Obstet. Gynecol. 62 (1983) 41 
[22] SANDERS, R. L.: The chemical composition of the lung. P. M. FARRELL: Lung Development: Biological and Clinical Perspectives, Vol. I. Academic Press, New York 1982

[23] YAVIN, E., A. ZUTRA: Separation and analysis of ${ }^{32} \mathrm{P}$-labeled phospholipids by a simple and rapid thin layer chromatographic procedure and its application to cultured neuroblastoma cells. Analyt. Biochem. 80 (1977) 430
J. G. Quirk, Jr.; M.D., Ph.D.

Department of Obstetrics and Gynecology University of Arkansas, School of Medicine 4301 West Markham, Slot 518

Little Rock, Arkansas 72201

USA 